\title{
Model Kebijakan Pemerintah dalam Pengaturan Pemanfaatan Sumber Daya Hayati oleh Negara Asing di Wilayah Pengelolaan Perikanan Indonesia
}

\author{
Irawati \\ Fakultas Hukum Universitas Islam Bandung \\ Jl. Rangga Gading No. 8 Bandung \\ Ira.wati66@gmail.com
}

\begin{abstract}
This research discusses: First, the practices of states in marine natural resources utilization by foreign countries. Second, regulation model of marine natural resources utilization by foreign countries to be able to give contribution for fishery industry in Indonesia. The method used in this research was normative juridical, The conclusions are first, the practices of coastal states in marine natural resources utilization by foreign countries have complied with the international sea law provisions considering some aspects, namely conservation, economic, and culture. Second, regulation and implementation models of natural resources implementation in Indonesia fishing area that can develop fishery industry in Indonesia are through an integrated fishing company by the establishment of a joint-venture company.
\end{abstract}

Key words : Utilization, natural, Indonesia fishery

\begin{abstract}
Abstrak
Penelitian ini mengandung permasalahan: pertama, praktek negara-negara dalam pemanfaatan sumber hayati laut oleh pihak asing. Kedua, model pengaturan pemanfaatan sumber daya hayati laut oleh pihak asing sehingga dapat memberikan kontribusi bagi industri perikanan Indonesia. Metode yang digunakan dalam penelitian ini adalah yuridis normatif. Hasil penelitian menyimpulkan bahwa: pertama, praktek negara-negara pantai dalam pemanfaatan sumber hayati laut oleh pihak asing, telah sesuai dengan ketentuan hukum laut internasional, yang mempertimbangkan berbagai aspek yaitu aspek konservasi, ekonomi dan kebudayaan. Kedua, model pengaturan dan pelaksanaan pemanfaatan sumber daya hayati di wilayah perikanan Indonesia yang dapat mengembangkan industri perikanan Indonesia adalah dengan melalui pendirian perusahaan penangkapan ikan terpadu, yaitu melalui pembentukan usaha patungan atau Joint Venture.
\end{abstract}

Kata kunci : Pemanfaatan, hayati, perikanan indonesia 


\section{Pendahuluan}

Indonesia termasuk negara yang kaya akan sumber daya alam. Secara teoritis sumber daya alam dan tingkat perekonomian suatu negara memiliki kaitan yang erat $^{1}$, dimana sumber daya alam akan menunjang pertumbuhan ekonomi yang pesat. ${ }^{2}$ Indonesia memiliki laut yang lebih luas dibandingkan daratannya, sehingga sangat penting bagi Indonesia untuk dapat mengelola laut untuk kemakmuran rakyatnya. Salah satu sumber daya laut yang sangat potensial adalah sumber daya hayati (perikanan) yang sangat penting bagi kelangsungan hidup manusia dan memiliki nilai ekonomis tinggi yang dapat menjadi modal bagi pembangunan Indonesia. Dalam pemanfaatan sumber daya hayati di wilayah perikanan Indonesia, pihak yang memanfaatkan tidak hanya warga negara atau perusahaan perikanan Indonesia tetapi juga Pemerintah Indonesia telah banyak memberikan izin kepada nelayan-nelayan asing dan perusahaan perikanan asing, antara lain nelayan dari Cina, Philipina dan Thailand yang didasarkan kepada persetujuan antarnegara di Zona Ekonomi Eksklusif (ZEE) Indonesia. Di samping pemberian izin berdasarkan persetujuan antar negara, pemanfaatan sumber daya hayati Indonesia juga dilaksanakan dalam kerangka kewajiban menurut hukum internasional.

Dari kegiatan nelayan dan perusahaan ikan asing tersebut di wilayah pengelolaan perikanan Indonesia yang telah dilaksanakan, belum ada pola pengaturan yang melindungi perikanan Indonesia dan nelayan Indonesia, sehingga merugikan perikanan Indonesia. ${ }^{3}$ Untuk itu perlu model pengaturan yang diarahkan kepada kepentingan ekonomi Indonesia dan perlindungan terhadap nelayan Indonesia.

Berdasarkan Pasal 7 ayat (1) Undang-Undang No. 31 Tahun 2004 tentang Perikanan, Menteri Kelautan dan Perikanan memiliki wewenang untuk melakukan pengelolaan perikanan di wilayah perikanan Indonesia, dengan menetapkan antara lain rencana pengelolaan perikanan, menetapkan jumlah tangkapan, jenis alat penangkap ikan, daerah penangkapan dan lain-lain.Terkait dengan hal ini, maka pemberian akses kepada pihak asing untuk memanfaatkan sumber daya hayati di

\footnotetext{
${ }^{1}$ Negara yang cenderung memiliki sumber pendapatan besar dari hasil bumi memiliki kestabilan ekonomi sosial yang lebih rendah dari pada negara-negara yang bergerak di sektor industri dan jasa, hal ini sebagaimana terjadi pada Indonesia. Kasus ini dalam bidang ekonomi sering disebut Dutch disease dapat disebabkan oleh berbagai hal misalnya tidak memiliki teknologi yang memadai dalam mengolahnya, korupsi, perang saudara, lemahnya pemerintahan dan lain-lain.

${ }^{2}$ Sumber Daya Alam, Diakses dari wikipedia, 28 November 2011.

${ }^{3}$ Antara lain Indonesia pada tahun 1979 mengadakan kerjasama dengan Jepang, tahun 2002 dengan Cina, 2003 dengan Philipina dan Thailand.
} 
wilayah perikanan Indonesia selain harus berdasarkan izin sebagaimana ditentukan dalam Undang-Undang Perikanan, juga Menteri Kelautan dan Perikanan harus dapat mengarahkan pemanfaatan tersebut untuk mengembangkan industri perikanan Indonesia dan ekonomi indonesia secara umum.

\section{Rumusan Masalah}

Berdasarkan latar belakang tersebut, maka dapat diidentifikasi permasalahan sebagai berikut: pertama, bagaimanakah praktek negara-negara dalam pemanfaatan sumber hayati laut oleh pihak asing? Kedua, bagaimanakah model pengaturan pemanfaatan sumber daya hayati laut oleh pihak asing sehingga dapat memberikan kontribusi bagi industri perikanan Indonesia?

\section{Tujuan Penelitian}

Adapun tujuan penelitian ini adalah, pertama, untuk mengetahui praktek negaranegara dalam pemanfaatan sumber hayati laut oleh pihak asing. Kedua, model pengaturan pemanfaatan sumber daya hayati laut oleh pihak asing sehingga dapat memberikan kontribusi bagi industri perikanan Indonesia.

\section{Metode Penelitian}

Spesifikasi penelitian adalah deskriptif analitis. Penelitian ini merupakan penelitian bidang hukum, yang bertujuan untuk memperoleh pemahaman dan mencari solusi terhadap permasalahan tentang pemanfaatan sumber daya hayati di wilayah pengelolaan perikanan Indonesia oleh pihak asing menurut Konvensi Hukum Laut 1982, maupun dalam praktek negara-negara termasuk praktek Indonesia sehingga akan dihasilkan suatu konsep pemanfaatan sumber daya alam yang dapat diarahkan kepada pengembangan ekonomi Indonesia.

Metode pendekatan yang digunakan dalam penelitian ini adalah metode pendekatan yuridis normatif dan komparatif. Yuridis normatif yaitu menganalisis secara kualitatif data sekunder berupa bahan hukum primer dan bahan hukum sekunder, sedangkan pendekatan yuridis komparatif yaitu dengan membandingkan dan menganalisis peraturan dan persetujuan-persetujuan yang diadakan oleh beberapa negara dalam kerjasama pemanfaatan sumber daya hayati laut. 
Proses analisis yuridis merupakan kegiatan penafsiran atau interpretasi dan konstruksi hukum (metode argumentasi) yang lazim dilakukan oleh para yuris atau ahli hukum. Interpretasi sebagai metode analisis yuridis ini meliputi interpretasi menurut bahasa, teleologis atau sosiologis, sistematis, historis-komparatif, dan futuristis. Konstruksi hukum (metode argumentasi) meliputi argumentum penganalogian, penyempitan hukum dan argumentum a contrario. ${ }^{4}$

\section{Hasil Penelitian dan Pembahasan}

\section{Yurisdiksi Teritorial Menurut Ketentuan Hukum Internasional}

Dalam hukum internasional selain kedaulatan yang merupakan hak fundamental negara, diakui pula bahwa negara dapat memiliki hak berdaulat (souvereign right). Hak berdaulat adalah hak suatu negara untuk mengeksplorasi dan mengeksploitasi sumber daya alam untuk kepentingan ekonominya. Adapun yang disebut hak berdaulat, menurut Black Law Dictionary yaitu: " "A unique right possessed by a State or its agencies that enables it to carry out its official function for public benefit, as distinguised from certain proprietary rights that it may posses like any other private person."

Kedaulatan negara merupakan kekuasaan negara yang tertinggi yang dapat direfleksikan secara intern dan ekstern. Kedaulatan secara ekstern adalah kekuasaan negara untuk melakukan hubungan dengan negara lain atau subjek hukum internasional lainnya, sedangkan kedaulatan secara intern adalah berupa kemerdekaan negara untuk mengatur segala sesuatu yang ada dalam yurisdiksinya. Kedaulatan negara secara intern terwujudkan dalam bentuk yurisdiksi teritorial, yaitu merupakan wewenang negara di dalam batas-batas wilayahnya atas dasar kedaulatan. Yurisdiksi teritorial dapat diartikan sebagai kewenangan untuk menetapkan berbagai peraturan yang berlaku secara nasional, kewenangan untuk memberlakukan peraturan perundang-undangan tersebut, dan kewenangan penegakan hukum yang dilaksanakan oleh pengadilan (untuk mengadili perkara perdata atau pidana). Dalam kaitan ini, D.J. Harris mengemukakan tentang yurisdiksi negara yaitu: " The power of state under international law to govern persons

\footnotetext{
${ }^{4}$ Sudikno Mertokusumo dan A Pitlo, Bab-bab tentang Penemuan Hukum, Citra Aditya Bakti, Bandung, 1993, hlm, 28.

${ }^{5}$ Bryan A. Garner, Black's Law dictionary, Eigth Edition, United State of America, Thomson West, 2009, hlm, 1430 .

${ }^{6}$ D.J. Harris, International Law, Sixth edition, Thomson Sweet and Maxell, London, 2004, hlm, 265.
} 
and proverty by its municipal law. It includes both the power to prescribe rules (prescriptive yurisdiction) and the power to enforce them (enforcement jurisdiction)"

Pengertian yurisdiksi teritorial dikemukakan oleh Lord Macmillan, yaitu: ${ }^{7}$ "It is an esential attribute of the sovereignty of this realm, as of all sovereignty independent status that is should process jurisdiction over all person and things within its territorial limits and in all causes civil and criminal arising within these limits". Dari pengertian tersebut maka dapat dikemukakan bahwa negara mempunyai yurisdiksi terhadap orang, benda dan peristiwa hukum perdata dan pidana yang terjadi di dalam batas-batas wilayahnya. ${ }^{8}$

Pada prinsipnya semua kapal yang berbendera suatu negara diasosiasikan sebagai wilayah negara bendera, sehingga hukum yang berlaku di atas kapal adalah hukum negara bendera. Hal ini dilandasi oleh 2 teori, yaitu: Teori Pulau Terapung (floating island theory) dan Teori Objektif. ${ }^{9}$ Meskipun berdasarkan teori pulau terapung kapal sebagai bagian dari wilayah negara bendera, namun apabila kapal tersebut mengganggu ketertiban dan keamanan negara pantai, maka negara pantai dapat melakukan suatu tindakan. Namun, hal ini dikecualikan pada kapal-kapal perang asing dan kapal pemerintah asing, yang mana pada jenis kapal tersebut memiliki imunitas. ${ }^{10}$

Yurisdiksi teritorial negara dalam kaitan dengan pemberlakuan dan penegakan hukum, yaitu berlakunya doktrin tindakan negara. Berdasarkan doktrin tindakan negara bahwa tindakan negara yang bersifat "iure emperii" yang dilakukan di dalam wilayahnya tidak dapat diuji keabsahannya. Artinya setiap tindakan negara dalam kapasitasnya sebagai tindakan negara berdaulat, yang dilakukan dalam wilayah kedaulatannya maka merupakan tindakan yang sah menurut hukum internasional. ${ }^{11}$ Yurisdiksi negara dalam pemberlakuan dan penegakan hukum terhadap orang asing

${ }^{7}$ J.G. Starke, Introduction to International Law, Butterworths, London, 1989, hlm, 123.

${ }^{8}$ D.J. Harris, International Law..., Op.Cit., hlm 266.

${ }^{9}$ J.G. Starke, Introduction to..., Op.Cit., hlm. 224. Berdasarkan Teori Pulau Terapung bahwa kapal dipandang sebagai bagian dari wilayah negara bendera kapal, sehingga hukum yang berlaku adalah hukum bendera kapal, yurisdiksi pengadilan teritorial atas kejadian-kejadian di atas kapal dikesampingkan. Teori Objektif yaitu imunitas diberikan kepada kapal asing tidak berdasarkan bahwa kapal sebagai wilayah asing, tetapi pengecualian diberikan oleh hukum setempat.

${ }^{10}$ Ibid, dikatakan bahwa kejahatan yang dilakukan di atas kapal-kapal perang asing dan kapal-kapal pemerintah asing lainnya pada saat sedang berada di pelabuhan suatu negara pantai berada dibawah yurisdiksi negara bendera kapal. Demikian pula jika kejahatan itu dilakukan terhadap warga negara negara pantai, atau akibat kejahatan itu mengganggu ketertiban dan keamanan negara pantai maka negara pantai tidak dapat melaksanakan yurisdiksi kriminal. Dalam hal demikian negara pantai hanya memiliki wewenang untuk mengusir kapal tersebut dan mengajukan protes kepada negara bendera kapal.

${ }^{11}$ Yudha Bhakti Ardiwisastra, Imunitas Kedaulatan Negara di Forum Pengadilan Asing, Alumni, Bandung, 1999, hlm, 289-298. Antara lain terkait dengan tindakan Pemerintah Indonesia yang melakukan nasionalisasi perusahaan Belanda di Indonesia, yang mana tindakan tersebut dinilai sebagai tindakan negara yang berdaulat, karena terkait dengan ketertiban umum dan kepentingan ekonomi Indonesia yang baru merdeka. 
dan milik asing terkait dengan ketentuan hukum internasional. Hukum Internasional memberikan perlindungan terhadap orang asing dan hak milik asing yang ada pada suatu negara, yang mana pada umumnya ditaati oleh negara-negara. Namun demikian, dalam keadaan tertentu ketentuan hukum internasional mengenai perlakuan terhadap orang asing dan milik asing tidak dapat dipertahankan, karena ada kepentingan lain yang lebih tinggi dan mendesak. ${ }^{12}$

Terkait dengan yurisdiksi teritorial intern, maka Indonesia memiliki kemerdekaan untuk mengatur segala sesuatu dalam wilayahnya. Hal ini terkait dengan penetapan aturan, permberlakuan dan penegakan aturan tersebut. Terkait dengan sumber daya alam, Pasal 33 ayat (3) Undang-Undang Dasar Negara Republik Indonesia 1945 menegaskan bahwa "bumi, air dan kekayaan alam dikuasai oleh negara dan dipergunakan sebesar-besar untuk kemakmuran rakyat". Menurut putusan Mahkamah Konstitusi hak menguasai negara bukan dalam makna negara memiliki, tetapi dalam pengertian bahwa negara hanya merumuskan kebijakan (beleid), melakukan pengaturan (regelendaad), melakukan pengurusan (besturdaad), melakukan pengelolaan (beheerdaad), dan melakukan pengawasan (toezichthoundendaad). ${ }^{13}$ Negara memiliki kewajiban agar sumber daya alam yang ada dalam wilayahnya atau dalam yurisdiksinya dapat terjaga kelestariannya untuk generasi yang akan datang. Dalam penerapan prinsip keadilan antargenerasi perlu diperhatikan pula keadilan dalam suatu generasi (intragenerational equity). ${ }^{14}$

\section{Hak-Hak Negara Lain Atas Sumber Daya Hayati Pada Perairan yang Berada Pada Yurisdiksi Nasional Negara Pantai Menurut Konvensi Hukum Laut 1982}

Konsep hak perikanan tradisional didasarkan kepada konsep kebebasan menangkap ikan di laut lepas yang berasal dari hukum kebiasaan internasional meskipun sekarang telah ada pembatasan tertentu. Dengan diakuinya rezim hukum negara kepulauan dan Zona Ekonomi Eksklusif (ZEE), maka negara-negara yang warga negaranya telah terbiasa melakukan penangkapan ikan di area tertentu di

${ }^{12}$ Dalam praktek Indonesia, pada kasus pengambilalihan dan nasionalisasi perusahaan-perusahaan milik Belanda menggambarkan pengecualian terhadap ketentuan hukum internasional tersebut.

${ }^{13}$ Pan Muhamad Faiz, "Konsep Penguasaan Negara Pasal 33 UUD 1945 dan Putusan Konstitusi”, www.jurnal hukum blogspot.com, diakses 22 Maret 2012.

${ }^{14}$ Catherine Redgwell, "Intergeneration Equity and Global Warming", dalam Course Materials on International on Environmental Law, Universitas Padjadjaran, Bandung, 1995, hIm, 53-55. "There is the consideration of intragenerational equity, which requires that equality shoul be achieved within generations, with the burden of preservation and benefit of exploitation balanced among member of that generation" 
laut lepas, yang kini berubah statusnya di bawah yurisdiksi negara pantai perlu diakomodasikan kepentingannya. Oleh karena itu, negara kepulauan harus mengakomodasikan hak penangkapan ikan tradisional (tradisional fishing right). Demikian pula pada ZEE negara pantai juga harus mengakomodasikan hak penangkapan ikan tradisional (tradisional fishing right).

Tradisional right to fish atau hak tradisional atas perikanan dilaksanakan di laut lepas berdasarkan kebebasan di laut lepas sebagaimana di atur dalam rezim hukum laut lepas. Sedangkan tradisional fishing right dilaksanakan pada bagian laut yang berada di bawah yurisdiksi negara pantai, yaitu pada perairan kepulauan dan pada ZEE. ${ }^{15}$ David Joseph Attard mengemukakan istilah "historical fishing right " di samping tradisional fishing right untuk menjelaskan hak penangkapan ikan tradisional pada ZEE. Untuk memberikan pemahaman tentang hak penangkapan ikan tradisional (tradisional fishing right), Hasjim Djalal mengemukakan kualifikasi dari hak penangkapan ikan tradisional, yaitu: ${ }^{16}$

(a) the actual existence of sufficiently long fishing activities must be established; (b) the area visited by the fishermen, that is, the fishing ground visited should be relatively constant; (c) fishermen themselves, in the sense that the right shall be granted only to the same fishermen who have visited the area tradisionally; (d) to equipment and vessel used as well as the amount of catch, in the sense that to qualify under the meaning of "tradisional fishing right " the vessel use should be relatively traditional."

Konsep "tradisional fishing right" hanya dapat diakui sepanjang memenuhi kualifikasi tersebut di atas. Konsep hak penangkapan ikan tradisional tidak boleh bertentangan dengan kepentingan nasional negara pantai, artinya hak ini perlu diatur sesuai arah kebijakan negara pantai di bidang perikanan, antara lain tidak bertentangan dengan pengembangan industri perikanan negara pantai, dan juga harus tidak menimbulkan kerugian terhadap posisi nelayan negara pantai. Hak penangkapan ikan tradisional negara tetangga yang langsung berdekatan tidak dapat secara otomatis dilaksanakan, artinya negara yang nelayannya secara tradisional telah terbiasa melakukan penangkapan ikan di area perairan kepulauan harus mengajukan hak tersebut. ${ }^{17}$

Pemanfaatan sumber daya hayati secara optimal yaitu pemanfaatan sumber daya hayati yang mempertimbangkan berbagai aspek, baik aspek biologi, ekonomi, $170-171$

${ }^{15}$ David Joseph Attard, The Exclusive Economic Zone in International Law, Oxford, Clarendon Press, 1987, hlm.

${ }^{16}$ Hasjim Djalal, Indonesia the Law of the Sea, CSIS, Jakarta, 1995, hlm. 161.

17 Ibid., hlm. 163. 
sosial maupun politik. Pertimbangan berbagai aspek ini bertujuan agar sumber daya hayati di ZEE di samping dapat memberikan manfaat sosial yang lebih luas juga terjaga kelestariannya. ${ }^{18}$ Untuk itu negara pantai memiliki kewajiban, sebagai berikut. ${ }^{19}(1)$ menetapkan kemampuan memanen sumber daya hayati (capacity to harvest); (2) dalam hal negara pantai tidak memiliki kemampuan menangkap ikan sesuai dengan jumlah tangkapan yang diperbolehkan, berkewajiban memberikan surplus dan jumlah tangkapan yang diperbolehkan kepada negara lain, terutama negara yang tak berpantai (Pasal 69), dan negara yang secara geografis tidak beruntung (Pasal 70) yaitu: (1) bekerjasama untuk menetapkan pengaturan yang adil bagi ikut berperannya negara berkembang tak berpantai pada kawasan dan subkawasan yang sama dalam hal negara pantai kemampuan penangkapannya telah mendekati titik kemampuan dan seluruh jumlah tangkapan yang diperbolehkan (Pasal 69 ayat 3); (2) bekerjasama untuk menetapkan pengaturan yang adil bagi ikut sertanya negara berkembang yang secara geografis tidak beruntung pada kawasan dan sub-kawasan yang sama, secara bilateral, regional, sub-regional, dalam hal kemampuan penangkapan negara pantai telah mendekati titik kemampuan dan seluruh jumlah tangkapan yang diperbolehkan (Pasal 70 ayat (3 dan 4)).

Negara pantai berkewajiban memanfaatkan sumber daya hayati di ZEE-nya secara optimal. Sesuai dengan Pasal 62 KHL 1982, negara pantai yang tidak mempunyai kemampuan untuk memanfaatkan seluruh TAC sumber daya hayati di ZEE-nya, berkewajiban memberikan hak akses atas surplus sumber daya hayati di ZEE-nya kepada pihak asing. Ketentuan ini didasarkan pada pertimbangan dari berbagai aspek, di samping aspek hukum juga aspek ekonomi, biologi dan lingkungan. ${ }^{20}$ Atas pertimbangan berbagai aspek tersebut negara pantai berkewajiban menetapkan potensi maksimum yang lestari (MSY), jumlah tangkapan yang diperbolehkan (TAC) dan kemampuan untuk memanen sumber daya hayati (Capacity to harvest). ${ }^{21}$

Kewajiban negara pantai menetapkan kemampuan memanen sumber daya hayati (capacity to harvest) di ZEE-nya, mempunyai kaitan yang erat dengan hak akses

\footnotetext{
${ }^{18}$ Reynaldo Gafindo Pohl, The Exclusive Economic Zone in the Light of the Negotiations of the Third United Nations Conference On The Law Of The Sea, dalam Francisco Orrego Vicuna., (ed), supra, No.. 94, hIm. 53.

${ }^{19}$ Made Pasek Dianta, Zona Ekonomi Ekskelusif Indonesia Berdasarkan Konvensi Hukum Laut 1982, Mandar Maju, Bandung, 2002, hIm. 18-23.

${ }^{20}$ Hugo Caminos, The Regime of Fisheries In The Exclusive Economic Zone, Francisco Orrego Vicuna, (ed), hIm. 145.

${ }^{21}$ Berdasarkan Pasal 61 ayat (1) dan Pasal 62 ayat (2) Konvensi Hukum Laut (KHL) 1982.
} 
negara asing atas surplus perikanan. Hal ini sebagaimana dikatakan oleh Hugo Caminos:22 "the right of the Coastal State to access its own capability för harvesting the living resources of its Exclusive Economic Zone is of fundamental importance, for it is this assessment that determine wether a surplus exists and therefore, whether other States may be granted acces to it."

Penetapan kemampuan untuk memanen sangat penting, karena melalui penetapan demikian baru dapat ditentukan ada atau tidak adanya surplus perikanan bagi pihak asing. ${ }^{23}$ Dalam memberikan hak akses atas surplus perikanan kepada pihak asing, KHL 1982 telah menetapkan hal-hal yang perlu menjadi pertimbangan bagi negara pantai, yaitu: ${ }^{24}$ (1) pentingnya sumber daya hayati di daerah itu bagi perekonomian negara pantai dan kepentingan nasional lainnya; (2) kebutuhan negara berkembang di kawasan dan subkawasan yang sama; (3) kebutuhan untuk mengurangi dislokasi ekonomi di negara-negara yang warganegaranya sudah biasa menangkap ikan di zona tersebut atau telah sungguh-sungguh melakukan riset dan identifikasi persediaan jenis ikan; (5) sejauh mana negara tak berpantai dan negara secara geografis tidak beruntung telah berperan pada ZEE negara pantai lainnya; (6) kebutuhan gizi penduduk masing-masing negara.

Konvensi menetapkan pula bahwa apabila perekonomian suatu negara pantai sangat bergantung pada eksploitasi sumber daya hayati di ZEE-nya, maka kewajiban untuk memberikan hak akses atas surplus perikanan kepada negara-negara lain tidak berlaku. Hal ini didasarkan kepada hakekat dan konsep ZEE yang terutama untuk memenuhi kepentingan ekonomi negara pantai. ${ }^{25} \mathrm{Di}$ samping itu pula dalam hukum internasional, berdasarkan hukum kebiasaan internasional telah diakui hak preferensi (preferential rights) negara pantai atas sumber daya hayati pada laut yang berdekatan dengan laut teritorialnya.

Dalam hal kemampuan negara pantai mendekati TAC, KHL 1982 tetap mewajibkan negara pantai memperhatikan kepentingan negara-negara berkembang yang merupakan negara-negara yang secara geografis tidak beruntung dan negaranegara yang tidak berpantai. Melalui suatu pengaturan yang adil baik secara bilateral, sub-regional maupun regional, negara-negara pantai harus memperbolehkan peran

\footnotetext{
${ }^{22}$ Hugo Caminos, dalam Francisco Orego Vicuna., (ed), Loc.Cit.

${ }^{23}$ Shigeru Oda, "Fisheries Under the United Nations Convention on the Law of the Sea", AJIL 1983, Vol 77, hlm. 744.

${ }^{24}$ Pasal 62 ayat (2), Pasal 69 ayat (3) KHL 1982, Pasal 70 ayat (3).

${ }^{25}$ Etty R. Agoes. " Konsepsi Economic Zone di Dalam Hukum Laut Internasional “, Jurnal Padjadjaran, Jilid VII, 1976, hlm. 16.
} 
serta negara-negara berkembang tersebut memanfaatkan surplus perikanan di ZEEnya. $^{26}$

\section{Praktek Negara-Negara dalam Kerjasama Pemanfaatan Sumber Daya Hayati}

Sebagian besar negara pantai melakukan kerjasama pemanfaatan perikanan dengan negara lain dilakukan di ZEE. Hal ini sebagaimana penelitian yang telah dilakukan oleh Carroz dan Savini pada tahun 1983, bahwa sampai dengan tahun 1975 telah terdapat 300 perjanjian bilateral dalam pemanfaatan sumber daya hayati di ZEE. Dalam penelitiannya, Carroz dan Savini mengelompokkan perjanjian internasional di bidang perikanan ke dalam 2 bentuk, yaitu: ${ }^{27}$ (a) bentuk I: Perjanjian Internasional di bidang perikanan yang merupakan komponen dan kerja sama yang lebih luas; (b) bentuk II: Perjanjian Internasional di bidang perikanan yang mengatur khusus masalah perikanan.

Perjanjian dalam bentuk ke-II dapat berlaku untuk jangka pendek, jangka menengah, dapat pula jangka panjang. Misalnya perjanjian antara Spanyol dan Mauritania yang berjangka waktu 50 tahun.

Selanjutnya dalam penelitiannya Carroz dan Savini mengelompokkan perjanjian internasional di bidang perikanan yang khusus mengatur masalah perikanan ke dalam dua kategori, yaitu Agreement providing for medium term co-operation in fisheries which are implemented periodically (normally on a year basis) dan The self contained agreements (short-, long- or medium term). ${ }^{28}$ Perjanjian kategori pertama merupakan suatu bentuk perjanjian kerjasama, dimana para pihak dapat memperpanjang perjanjian setiap tahun. Perjanjian semacam ini dapat memberikan fleksibilitas kepada pihakpihak yang bersangkutan untuk secara periodik setiap tahun merundingkan perjanjian untuk kemudian kesepakatan yang telah dicapai dimasukan ke dalam suatu protokol. Bagi negara pantai perjanjian kategori pertama lebih memberikan keleluasaan, karena negara pantai dapat menyesuaikan perjanjian sesuai dengan kebijakan perikanannya. Namun, bagi negara bendera kapal hal ini tidak memberikan kepastian tentang kelanjutan dari operasi penangkapan ikan mereka. Perjanjian kategori kedua merupakan perjanjian bidang perikanan, dimana dalam

\footnotetext{
${ }^{26}$ Pasal 69 ayat (3) dan Pasal 70 ayat (3) KHL 1982.

${ }^{27}$ Barbara Kwiatkowska, The 200 Mile Exclusive Economic Zone in the New Law of the Sea, Martinus Nijhof, London, 1989, hlm. 65.

${ }^{28}$ Sebagaimana dikutip oleh Chairul Anwar, ZEE dalam Hukum Internasional, Sinar Grafika, Jakarta, 1995, hlm. 89.
} 
perjanjian jenis ini ditentukan jangka waktu tertentu, di samping itu memuat pula pengaturan pengakhiran perjanjian. ${ }^{29}$

Perjanjian internasional merupakan instrumen yuridis yang berisi kehendak dan persetujuan negara-negara. Melalui perjanjian internasional negara-negara dapat menggariskan dasar kerjasama, mengatur berbagai kegiatan dan menyelesaikan berbagai masalah. ${ }^{30}$ Demikian pula dalam perjanjian bilateral di bidang perikanan, negara-negara menentukan dasar kerjasama, mengatur berbagai kegiatan, dan menyelesaikan berbagai masalah. Pada umumnya negara-negara membentuk perjanjian bilateral bidang perikanan sebagai framework agreement atau perjanjian induk. ${ }^{31}$ Dalam praktek beberapa negara, pengaturan pemberian hak akses atas surplus perikanan di ZEE di samping melalui perjanjian internasional, juga dengan cara pembentukan kontrak-kontrak Joint Venture.

Dalam konteks ekonomi , arti Joint Venture adalah suatu persetujuan di antara dua pihak atau lebih untuk melakukan kerja sama dalam suatu kegiatan..$^{32}$ Istilah Joint Venture dapat pula dilihat dalam Black's Law Dictionary, yaitu :33

"A business undertaking by two or more persons engaged in single defined project. The necessary elements are 1) an express or implied agreement, 2) a common purpose that the group intends to carry out, 3) shared profits and losses, 4,) each member 's equal voice in controlling the project-also termed. A legal entity in the nature of partnership engaged in the prosecution of a particular transaction for manual profit. An Association of persons jointly undertaking some commercial enterprise. It requires a community of interest in the performance of the subject matter, a right to direct or govern the policy In connection therewith, and duty which may he altered by agreement to share both in profit and losses."

Dijelaskan bahwa Joint Venture adalah suatu badan hukum (legal entity) yang berwujud suatu perserikatan (in the nature of a partnership) yang diperjanjikan dalam usaha bersama sebagai suatu transaksi khusus untuk mencari keuntungan bersama. ${ }^{34}$ Pengertian Joint Venture atau usaha patungan dikemukakan pula oleh Sunaryati Hartono, yaitu: 35 "Joint Venture adalah setiap usaha bersama antara modal Indonesia

\footnotetext{
${ }^{29}$ Ibid.

${ }^{30}$ Boer Mauna, Hukum Internasional PengertianPeranan dan Fungsi Dalam Era Dinamika Global, Alumni, Bandung,

${ }^{31}$ Chairul Anwar, ZEE dalam..., Op.Cit., hlm. 94-95.

${ }^{32}$ Amirizal, Hukum Bisnis Deregulasi Dan Joint Venture di Indonesia Teori dan Praktek, Djambatan, Bandung, 1996,

${ }^{33}$ Bryan A. Garner (ed), Black's Law..., Op.Cit, hlm. 843.

${ }^{34}$ Lihat, Sornarajah M., Law of International Joint Venture, Longman, Singapore, 1992, hlm. 10.

${ }^{35}$ Sunaryati Hartono, Masalab — masalah Dalam Joint Venture Antara Modal Asing Dan Modal Indonesia, Alumni,
} hlm. 82 . hlm. 80 . Bandung, 1974, hlm. 6. 
dan modal asing, baik ia merupakan usaha bersama antara swasta dengan swasta, pemerintah dengan swasta atau pemerintah dengan pemerintah." Sebagai kontrol negara terhadap perusahaan multinasional yang ingin menanamkan modal di negaranya, maka perusahaan asing yang bersangkutan diharuskan bekerjasama dengan perusahaan lokal dan membentuk badan hukum nasional. Dalam bentuk badan hukum nasional, perusahaan yang merupakan PMA dapat dijadikan tunduk kepada hukum nasional negara tuan rumah. ${ }^{36}$

Pemberian kesempatan kepada pihak asing atas perikanan di samping dapat dilakukan dalam bentuk kontrak Joint Venture, dapat pula dilaksanakan melalui sistem lisensi. Menurut kamus lnggris-Indonesia, istilah “Lisensi” berasal dan bahasa Inggris "Licence" yang berarti "surat izin", yaitu izin untuk melakukan suatu usaha. Dalam bidang perikanan istilah "lisensi" dipergunakan bagi kapal penangkap ikan asing yang ingin memanfaatkan potensi laut negara pantai. Sistem lisensi sering juga digunakan oleh negara pantai untuk pemberian kesempatan kepada pihak asing untuk memanfaatkan sumber daya hayati. Sistem ini dapat didasarkan kepada perjanjian bilateral, tetapi dapat pula tidak didasarkan kepada penjanjian bilateral. Pada umumnya sebagian besar negara-negara dalam memberikan kesempatan kepada pihak asing untuk memanfaaatkan sumber daya hayati, melalui sistem lisensi maupun usaha patungan (joint venture), ataupun perpaduan keduanya, dengan didasarkan kepada perjanjian bilateral antar negara sebagai perjanjian payung (umbrella Agreement).

\section{Pengaturan dan Praktek Negara-Negara dalam Pemanfaatan Sumber Daya Hayati di ZEE Oleh Pihak Asing}

Banyak negara dalam memberikan kesempatan kepada pihak asing untuk memanfaatkan sumber daya hayati di ZEE-nya didasarkan kepada pengaturan hak akses atas surplus perikanan, sebagaimana yang ditetapkan oleh KHL 1982. ${ }^{37}$ Seperti Cina memberikan kesempatan kepada negara asing untuk memanfaatan sumber daya hayati di ZEE-nya dalam bentuk hak akses atas surplus perikanannya. ${ }^{38}$ Demikian pula Niue melalui Teritorial Sea And Exclusive Economic Zone Act $1996^{39}$, Madagascar melalui Decree No. 94-112 Establishing the General Organization of Maritime

\footnotetext{
${ }^{36}$ Sornarajah M., Law of International..., Op.Cit., hlm.13.

${ }^{37}$ Law of The Sea Buletin No. 38 United Nation, New York, 1998, hlm. 28-31.

${ }^{38}$ Law of The Sea Buletin No 37, United Nation, New York, 1998, hlm. 35-57.

${ }^{39}$ Law of the Sea Buletin No 33, United Nations, New York 1998, hlm. 55-77. Lihat pasal 20-29.
} 
Fishing, Cuba rnelalui decree No. 2 of February 24, 1977 dalam Pasal 4 menetapkan:40 "To promote optimum use of the living resources of the economic zone, the Republic of Cuba will, by concluding the corresponding agreement, give other States acces to the surplus of the allowable catch of species, inaccordance with the terms, condition, and regulations in force."

Demikian pula Venezuela melalui Act Establishing an Exclusive Economic Zone Along Coasts of the Mainland and Islands of the Republic of Venezuela 1987, menetapkan hak akses atas surplus perikanan bagi negara asing. ${ }^{41}$ Meksiko melalui Act of 10 February 1976 Regulating the Provisions of Paragraph 8 of Article 27 of the Political Constitution of the United Mexican States concerning the Exclusive Economic Zone, dalam Pasal 8 menetapkan dapat mengizinkan kapal asing untuk memanfaatkan surplus perikanan di ZEE-nya :42 "When the total allowable catch of a species is greater than the fishing and hunting capacity of Mexican vessels, the Federal Executive Branch shall allow foreign vessel access to the surplus of the allowable catch, in accordance with the national interest and under the conditions set forth in the Federal Fishery Promotions Act."

Cina menetapkan dalam memberikan hak akses kepada pihak asing untuk memanfaatkan ZEE-nya harus dilakukan dengan terlebih dahulu diadakan perjanjian antara Pemerintah Cina dengan negara pihak asing yang bersangkutan. ${ }^{43}$ Hal yang sama ditetapkan pula oleh beberapa negara seperti, Kuba melalui Perjanjian Internasional memberi akses atas surplus perikanan kepada negara asing. Dapat dikatakan bahwa pada umumnya negara-negara pantai dalam memberikan hak akses atas surplus perikanan di ZEE-nya kepada pihak asing, dilakukan melalui perjanjian bilateral. ${ }^{44} \mathrm{Hal}$ ini memperlihatkan bahwa perjanjian internasional selain sebagai sumber hukum internasional juga sebagai sarana untuk mewujudkan kerjasama antar bangsa lebih memberi jaminan kepastian hukum bagi para pihak.

Terkait dengan prakteknegara-negara dalam rangka pemanfaatan sumber daya hayati laut, dapat dikemukakan beberapa persetujuan kerja sama yang dilakukan oleh beberapa negara seperti yang dilaksanakan oleh Amerika, Cina, Jepang, Australia, Korea Selatan, New Zealand, dan Solomon Island. Dari persetujuan-persetujuan tersebut peneliti dapat mencatat beberapa hal yang sangat penting bagi pengembangan industri perikanan.

\footnotetext{
${ }^{40}$ Ibid, hlm. 477-479.

${ }^{41}$ Ibid, hlm. 295-302.

${ }^{42}$ Robert W. Smith, Exclusive Economic Zone Claims An Analysis and Primary Documents, Martinus Nijhoff Publishers, 1986, hlm. 109-110.

${ }^{43}$ Law of the Sea Bulletin, Op.Cit. Article 5 Exclusive Economic Zone And Continental Shelf Act (Adopted at the third session of the Standing Committee of the Ninth National People's Congress, 26 June 1998).

${ }^{44} \mathrm{Hal}$ ini dapat dilihat dari beberapa ketentuan tentang ZEE beberapa negara, dalam Robert W. Smith, Loc.Cit.
} 
Persetujuan yang diadakan antara Amerika dengan Cina, merupakan bentuk perjanjian campuran antara agreement providing for medium term cooperation in fisheries which are implemented periodically (normally on a year basis) dan self contained agreement. Walaupun persetujuan ini telah ditentukan masa berlakunya, yaitu sampai dengan I Juli 1990, namun dalam jangka waktu tersebut beberapa ketentuan seperti alokasi surplus, lokasi penangkapan ikan dapat diperbaharui secara periodik setiap tahun. Hal ini memberikan keleluasaan bagi negara pantai untuk menyesuaikan perjanjian dengan kondisi atau kebijakan perikanan nasionalnya. Ketentuan-ketentuan yang terdapat dalam persetujuan ini, nampaknya di samping persetujuan telah sesuai dengan ketentuan KHL 1982, juga dalam persetujuan ini selain mempertimbangkan aspek konservasi, juga sangat mempertimbangkan aspek ekonomi.

Kerjasama antar negara dalam pemanfatan sumber daya alam termasuk dalam kerjasama bidang ekonomi. Prinsip saling memberikan manfaat dan adil merupakan hal yang sangat penting dalam kerjasama ekonomi, hal ini didasarkan pula kepada prinsip timbal balik. Sifat hubungan kerjasama yang saling memberi manfaat dan berkeadilan dapat terlihat dari tujuan persetujuan, yaitu selain untuk dicapainya pemanfaatan sumber daya hayati secara optimal, juga bertujuan untuk melaksanakan konservasi dalam rangka pengelolaan sumber daya hayati yang rasional, serta untuk rnengembangkan industri perikanan AS. Tujuan kerjasama ini, dijabarkan dalam ketentuan-ketentuan persetujuan yang merefleksikan tujuan-tujuan kerjasama tersebut, seperti ketentuan tentang kewajiban Cina untuk memberikan data dan informasi biologi, kerjasama riset ilmiah, dan perluasan akses pasar bagi produkproduk perikanan AS.

Dalam menentukan alokasi bagi pihak asing untuk memanfaatkan surplus perikanannya, Pemerintah AS mempertimbangkannya dari berbagai aspek baik aspek hukum, aspek ekonomi maupun aspek konservasi sesuai dengan KHL 1982. ${ }^{45}$ Sebagai imbalan atas diberikannya hak akses tersebut, sebagaimana yang ditentukan Pasal V Persetujuan, Pemerintah Cina harus bekerja sama dan membantu AS dalam mengembangkan industri penangkapan ikan dan memajukan ekspor perikanan. Di samping itu, Pemerintah Cina harus memberikan informasi berkenaan dengan teknik dan administrasi untuk masuknya produk perikanan AS ke pasar Cina, pemberian data-data ekonomi, bantuan tenaga ahli, mempermudah alih teknologi penangkapan ikan dan pemerosesan ikan kepada industri penangkapan ikan AS.

${ }^{45}$ Lihat Pasal 62 Ayat (3) KHL 1982. 
Selanjutnya yang dapat dicatat dari persetujuan antara Australia dengan Jepang adalah meskipun persetujuan antara Australia dengan Jepang ini ditandatangani jauh sebelum terbentuknya KHL 1982, namun persetujuan ini mengatur hal-hal yang serupa dengan ketentuan KHL 1982 tentang pemanfaatan sumber daya hayati pada ZEE. Dalam Pasal I Persetujuan tersebut dinyatakan bahwa kerjasama antara kedua negara ditujukan untuk melaksanakan konservasi dan pemanfaatan secara optimum sumber daya hayati. Selain itu, Pasal III Persetujuan menetapkan bahwa dalam melaksanakan hak berdaulatnya di Zona Perikanan Australia (Australian Fishing Zone), Pemerintah Australia akan menetapkan JTB serta alokasi dan bagian surplus perikanan bagi kapal-kapal penangkap ikan Jepang. Ketentuan ini serupa dengan ketentuan Pasal 61 dan Pasal 62 KI-IL 1982 mengenai kewajiban untuk melaksanakan konservasi dan pemanfaatan secara optimum.

Untuk menjamin pelaksanaan persetujuan, dan untuk melindungi kepentingan Australia dalam pelaksanaan konservasi, Pemerintah Jepang memberikan jaminan bahwa kapal-kapal penangkap ikannya akan mentaati ketentuan-ketentuan yang terdapat dalam Persetujuan. Di samping itu, Pemerintah Jepang akan melakukan upaya-upaya agar kapal penangkap ikan Jepang yang tidak memiliki izin, tidak melakukan penangkapan ikan pada Zona Perikanan Australia. Hal ini merupakan bentuk tanggung jawab negara bendera untuk mentaati peraturan negara pantai dan tanggung jawab untuk mentaati persetujuan.

Selanjutnya, persetujuan antara Korea dan Kepulauan Solomon secara keseluruhan hampir sama dengan persetujuan yang dilaksanakan antara Jepang dan Australia namun, sebagai catatan, dalam persetujuan ini diatur pula mengenai tindakan-tindakan yang dapat dilakukan oleh Pemerintah Kepulauan Solomon dalam hal penahanan atau penangkapan terhadap kapal penangkap ikan Korea dan awaknya. Persetujuan antara Kepulauan Solomon dengan Korea ini dapat dikategorikan dalam Selfcontained agreement. Persetujuan ini tidak menetapkan jangka waktu berlakunya, namun mengatur mengenai cara berakhirnya perjanjian, yaitu 12 bulan setelah salah satu pihak memberikan nota tentang keinginan untuk mengakhiri persetujuan.

Adapun persetujuan antara New Zealand dengan Jepang, substansinya memuat ketentuan-ketentuan yang serupa seperti pada perjanjian antara AS dengan Cina, Australia dengan Jepang dan antara Korea dengan Kepulauan Solomon. Pelaksanaan konservasi sumber daya hayati juga dilaksanakan melalui kerjasama antar kedua 
negara dalam riset ilmiah kelautan di daerah Zona New Zealand. Kerja sama tersebut dilaksanakan secara bilateral, dan bilamana perlu dapat dilaksanakan melalui organisasi internasional, sesuai dengan Antartic Treaty yang ditandatangani di Washington pada 1959. Di samping itu, Pemerintah Jepang harus memberikan data dan informasi statistik biologi sebagaimana yang diminta oleh pemerintah New Zealand.

Dalam rangka pengembangan industri perikanan New Zealand, kedua pemerintah sepakat bekerja sama untuk memfasilitasi kerjasama antara perusahaan kedua negara untuk pemrosesan dan pemasaran perikanan dari New Zealand. Di samping itu, Pemerintah Jepang membuka selebar-lebarnya akses pemasaran hasil perikanan dan produk perikanan New Zealand. Berdasarkan kesepakatan untuk memfasilitasi perusahaan swasta kedua negara, maka hak akses dilakukan pula melalui usaha patungan.

Persetujuan bilateral di bidang pemanfaatan sumber daya hayati di ZEE dikaitkan dengan pendapat Carroz dan Saviny sebagaimana telah diuraikan sebelumnya, maka Persetujuan antara AS dan Cina, New Zealand dengan Jepang menerapkan bentuk perjanjian campuran antara kategori pertama dan kedua. Sedangkan Australia dan Kepulauan Solomon menerapkan perjanjian dalam kategori kedua. Dapat menjadi catatan bahwa Perjanjian antara AS dengan Cina di samping memberikan keleluasaan kepada negara pantai, juga dari segi substansi sangat memperhatikan berbagai aspek kerja sama dalam pemanfaatan sumber daya hayati.

Selanjutnya kita lihat perjanjian kerjasama perikanan yang dilaksanakan Indonesia. Secara historis Indonesia telah memberikan kesempatan kepada pihak asing untuk memanfaatkan ZEE Indonesia, yaitu dengan melalui pesetujuan kerja sama antar negara yaitu dengan Cina, Thailand dan Philipina. Ketiga Perjanjian tersebut, bukan merupakan perjanjian perikanan dalam rangka pemanfaatan surplus perikanan, sebagaimana yang dikehendaki oleh KHL 1982. Dalam Perjanjian ini jelas dinyatakan bahwa perjanjian kerja sama ini merupakan pemanfaatan bagian dan JTB/TAC sumber daya hayati ZEE Indonesia.

Secara umum dari ketiga persetujuan ini, berisi ketentuan-ketentuan yang sifatnya teknis, meliputi Pasal 1 tentang tujuan dibentuknya Persetujuan, Pasal II mengatur tentang pemberian hak akses. Selanjutnya Pasal III mengatur tentang jenis alat penangkap ikan, kapal penangkap ikan dan zona penangkapan ikan. Pasal IV mengatur tentang pelaksanaan hak-hak, Pasal V tentang amandemen, Pasal VI tentang 
penyelesaian sengketa, Pasal VII berlakunya perjanjian, dan 3 buah appendix, masingmasing mengatur pelabuhan tempat mendarat dan atau sebagal check point, daerah penangkapan ikan untuk jenis alat penangkap ikan purse-seine, long-line, drift gillnet dan pukat ikan, serta jumlah dan ukuran kapal penangkap ikan dan jenis alat penangkap ikan yang boleh digunakan di ZEE Indonesia.

Sebagaimana persetujuan-persetujuan yang telah dibahas sebelumnya, hal-hal yang dianggap penting dan pada umumnya yang diatur dalam perjanjian pemanfaatan sumber daya hayati meliputi: (a) kerja sama dalam riset ilmiah kelautan dalam rangka konservasi dan pengelolaan sumber daya hayati di ZEE; (b) kerja sama alih teknologi penangkapan, dan pengolahan ikan yang bertujuan untuk mengembangkan industri perikanan nasional; (c) perluasan akses pasar bagi produkproduk perikanan negara pantai baik yang dihasilkan oleh nelayan asing maupun nelayan lokal; (d) pengaturan tentang sanksi terhadap pelanggaran-pelanggaran perjanjian; (e) jaminan negara bendera untuk bertanggung jawab dipatuhinya perjanjian dan ketentuan perundang-undangan negara pantai.

Persetujuan yang diadakan oleh Indonesia dalam pemanfaatan sumber daya hayati tidak sesuai dengan KHL 1982 dan sangat tidak mempertimbangkan aspekaspek penting sebagaimana perjanjian perikanan yang telah dilaksankan oleh negaranegara lain tersebut.

Dari semua perjanjian yang telah dibahas yang paling komprehensif adalah persetujuan yang diadakan antara Amerika dengan Cina. Persetujuan tersebut merupakan bentuk perjanjian campuran antara agreement providing for medium term cooperation in fisheries which are implemented periodically (normally on a year basis) dan self contained agreement. Selain substansinya memuat hal-hal yang sangat penting bagi perkembangan perikanan Amerika, persetujuan ini juga telah ditentukan masa berlakunya, yaitu sampai dengan I Juli 1990. Dalam jangka waktu tersebut beberapa ketentuan seperti alokasi surplus, lokasi penangkapan ikan dapat diperbaharui secara periodik setiap tahun. Hal ini memberikan keleluasaan bagi negara pantai untuk menyesuaikan perjanjian dengan kondisi atau kebijakan perikanan nasionalnya.

\section{Ketentuan Nasional Pengelolaan Sumber Daya Hayati Laut}

Pemerintah Indonesia telah mengeluarkan Undang-Undang No. 31 Tahun 2004 Tentang Perikanan, yang kemudian diubah oleh Undang-Undang No. 45 Tahun 2009 
tentang Perubahan Atas Perikanan No. 31 Tahun 2004 tentang Perikanan. UndangUndang ini merupakan dasar hukum bagi kegiatan-kegiatan perikanan di wilayah perikanan Indonesia. Pengelolaan perikanan, menurut Pasal 2 dilakukan berdasarkan azas manfaat, keadilan, kemitraan, pemerataan, keterpaduan, keterbukaan, efisiensi, dan kelestarian yang berkelanjutan. Wilayah Pengelolaan Perikanan (WPP) yang tunduk pada undang-undang ini meliputi: perairan Indonesia (sebagaimana ditetapkan dalam Undang-Undang No. 6 Tahun 1996), zona ekonomi eksklusif (ZEE), sungai, danau, waduk, rawa dan genangan air lainnya yang dapat diusahakan serta lahan pembudidayaan ikan yang potensial di wilayah Republik Indonesia. ${ }^{46}$ Undang-undang ini pada dasarnya hanya memberikan hak melakukan usaha perikanan di wilayah pengelolaan perikanan Republik Indonesia hanya bagi warga negara Republik Indonesia atau Badan Hukum Indonesia ${ }^{47}$, dan mewajibkan setiap orang atau badan hukum yang melakukan usaha penangkapan ikan tersebut untuk memiliki surat izin usaha penangkapan ikan. ${ }^{48}$ Dalam hal pihak asing, maka berdasarkan Pasal 30 Undang-Undang No. 31 Tahun 2004 harus didahului dengan perjanjian antar negara sebagai perjanjian payung. Badan hukum asing hanya dapat melakukan penangkapan ikan di wilayah perikanan Indonesia hanya pada wilayah ZEE Indonesia, sedangkan pengaturan tentang akses dan pengaturan lainnya ditetapkan oleh Pemerintah.

Selanjutnya terkait dengan perikanan di WPP Indonesia diatur oleh Peraturan Menteri Kelautan dan Perikanan No. 14 Tahun 2011 dan Peraturan Menteri kelautan No. 49 Tahun 2011 tentang Usaha Perikanan Tangkap ( Perubahan Permen No 14 Tahun 2011). Peraturan Menteri Kelautan dan Perikanan No 14 Tahun 2011 ini merupakan peraturan pelaksanaan bagi Undang-Undang No. 6 Tahun 1996 tentang Perairan Indonesia dan Undang-Undang No. 31 Tahun 2004 tentang Perikanan, khususnya merupakan pelaksanaan dari Pasal 32.

Secara garis besar, peraturan menteri ini mengatur hal-hal yang harus dipenuhi oleh perusahaan perikanan ${ }^{49}$ di Wilayah Pengelolaan Perikanan (WPP) Republik Indonesia, yaitu mengenai perizinan, pungutan pengusahaan perikanan (PPP), dan pungutan hasil perikanan (PHP). Jenis perizinan usaha perikanan tangkap, menurut

\footnotetext{
${ }^{46}$ Lihat Pasal 5 ayat 1 UU No.31 Tahun 2004.

${ }^{47}$ Lihat Pasal 29 ayat 1 UU No. 31 Tahun 2004.

${ }^{48}$ Lihat Pasal 26 ayat 1 UU No. 31 Tahun 2004.

${ }^{49}$ Yang dimaksud dengan perusahaan perikanan, menurut Pasal 1 (7), adalah perusahaan yang melakukan usaha dan dilakukan oleh warga negara Republik Indonesia atau badan hukum Indonesia.
} 
ayat 2 meliputi: a) Surat Izin Usaha Perikanan (SIUP); b) Surat Izin Penangkapan Ikan (SIPI); c) Surat Izin Kapal Pengangkut Ikan (SIKPI). Pungutan pengusahaan perikanan (PPP) dikenakan terhadap perusahaan perikanan Indonesia yang memperoleh SIUP, RAPIPM, dan SIKPI, sebagai imbalan atas kesempatan yang diberikan oleh Pemerintah Indonesia untuk melakukan usaha perikanan dalam wilayah pengelolaan perikanan Republik Indonesia.

Orang atau badan hukum asing dapat diberi kesempatan untuk melakukan usaha penangkapan ikan di WPP Republik Indonesia melalui investasi usaha pengolahan dengan pola investasi perikanan tangkap terpadu. Setiap orang atau badan hukum asing yang akan melakukan usaha perikanan tangkap terpadu diwajibkan untuk menggunakan fasilitas penanaman modal asing (PMA) atau penanaman modal dalam negeri (PMDN), dengan mendirikan usaha perikanan tangkap terpadu berbadan hukum dan berkedudukan di Indonesia. Hal ini sebagaimana ditegaskan pula dalam Permen No 49 tahun 2011 Pasal 49 ayat 1, orang atau badan hukum asing tersebut dapat mengadakan kerjasama dengan orang atau badan hukum Indonesia yang bergerak di bidang usaha perikanan tangkap dalam bentuk usaha patungan. Selanjutnya Pasal 50 Permen no 49 Tahun 2011 menegaskan bahwa, setiap orang atau badan hukum asing yang akan melakukan usaha penangkapan ikan harus melakukan investasi usaha pengolahan dengan pola usaha perikanan tangkap terpadu. Pola usaha perikanan tangkap terpadu sebagaimana dimaksud dilakukan dengan membangun dan/atau memiliki sekurang-kurangnya berupa UPI (unit Pengolahan ikan) di dalam negeri. SIPI diterbitkan jika pemegang SIUP di bidang penanaman modal telah membangun UPI.

\section{Penutup}

Berdasarkan uraian permasalahan dan analisis di atas, disimpulkan sebagai berikut. Pertama, praktek negara-negara pantai dalam pemanfaatan sumber hayati laut oleh pihak asing telah sesuai dengan ketentuan hukum laut internasional, yang mempertimbangkan berbagai aspek yaitu aspek konservasi, ekonomi dan kebudayaan. Kedua, model pengaturan dan pelaksanaan pemanfaatan sumber daya hayati di wilayah perikanan Indonesia yang dapat mengembangkan industri perikanan Indonesia adalah dengan melalui pendirian perusahaan penangkapan ikan terpadu, dilakukan dengan melalui pembentukan usaha patungan atau Joint Venture dilanjutkan dengan lisensi yang 
didahului dengan perjanjian antar negara sebagai perjanjian payung dan kategori perjanjian adalah campuran antara agreement providing for medium term cooperation in fisheries which are implemented periodically dan the self contained agreement (medium term) sebagaimana yang dilaksanakan oleh Amerika dengan Cina.

\section{Daftar Pustaka}

A Garner, Bryan, Black's Law dictionary, Eigth Edition, Thomson West, United State of America, 2009.

Amirizal, Hukum Bisnis Deregulasi Dan Joint Venture di Indonesia Teori dan Praktek, Djambatan, Bandung 1996.

Anwar, Chairul, ZEE dalam Hukum Internasional, Sinar Grafika, Jakarta, 1995.

Bhakti, Yudha, Ardiwisastra, Imunitas Kedaulatan Negara di Forum Pengadilan Asing, Alumni, Bandung, 1999.

Caminos, Hugo, The Regime of Fisheries In The Exclusive Economic Zone, Francisco Orrego Vicuna, (ed), Westview Press, Colorado, 1984.

Cesar Lupinacci, Julio., "The Legal Status of the Exclusive Economic Zone in the 1982 Convention on the Law of the Sea" dalam FA Latin American Perspective, Westview Press, Boulder, Colorado, 1984.

Djalal, Hasjim, Indonesia the Law of the Sea, CSIS, Jakarta, 1995. , Perjuangan Indonesia Di Bidang Hukum Laut, Binacipta, Bandung, 1979.

Gafindo Pohl, Reynaldo, "The Exclusive Economic Zone in the Light of the Negotiations of the Third United Nations Conference On The Law Of The Sea", The Exclusive Economic Zone, Francisco Orrego Vicuna (ed), Boulder Co., 1984.

Harris, D.J., International Law, Sixth edition, Thomson Sweet and Maxell, London, 2004.

Hartono, Sunaryati, Masalah-Masalah dalam Joint Venture Antara modal asing dan Modal Indonesia, Alumni, Bandung, 1974.

Joseph Attard, David, The Exclusive Economic Zone in International Law, Clarendon Press, Oxford,1987.

Kwiatkowska, Barbara, The 200 Mile Exclusive Economic Zone in The New Law of the Sea, Martinus Nijhof, 1989.

Mauna, Boer, Hukum Internasional Pengertian Peranan dan Fungsi dalam Era Dinamika Global, Alumni, Bandung, 2000.

Mertokusumo, Sudikno dan A Pitlo, Bab-bab tentang Penemuan Hukum, Citra Aditya Bakti, Bandung, 1993.

Misbach Muhjidin, Atje, Status Hukum Perairan Kepulauan Indonesia dan Hak Lintas Kapal Asing, Alumni, Bandung, 1993. 
Muhamad Faiz, Pan, “Konsep Penguasaan Negara Pasal 33 UUD 1945 dan Putusan Konstitusi", www.jurnal hukum blogspot.com, diakses 22 Maret 2012.

Pasek Dianta, Made, Zona Ekonomi Eksklusif Indonesia Berdasarkan Konvensi Hukum Laut 1982, Mandar Maju, Bandung, 2002.

R. Agoes, Etty, “ Konsepsi Economic Zone” di dalam Hukum Laut Internasional “, Majalah Padjadjaran, Jilid VII, 1976.

Redgwell, Catherine, "Intergeneration Equity and Global Warming", dalam Course Materials on International on Environmental Law, Universitas Padjadjaran, 1995.

Shigeru, Oda, "Fisheries Under the United Nations Convention on the Law of the Sea", AJIL, Vol 77, 1983.

Smith, Robert W., Exclusive Economic Zone Claims An Analysis and Primary Documents, Martinus Nijhoff Publishers, 1986.

Sornarajah, Law of International Joint Venture, Longman Inc, Singapora, 1992.

Starke, J.G., Introduction to International Law, Butterworths, London, 1989.

Law of The Sea Buletin No. 38 United Nation, New York, 1998.

Law of The Sea Buletin No. 37, United Nations, New York, 1998.

Law of the Sea Buletin No. 33, United Nations, New York, 1998.

Law of the Sea Buletin No. 46, United Nations, New York, 2001.

UUD 1945

UU No. 31 Tahun 2004 tentang Perikanan

UU No. 45 Tahun 2009 tentang Perubahan Terhadap UU No 31 Tahun 2004

UU No 32 Tahun 2004 tentang Pemerintah Daerah

UU No 25 Tahun 2007 tentang Penanaman modal

Peraturan Menteri Kelautan dan Perikanan No 14 Tahun 2011 tentang Usaha Perikanan

Peraturan Menteri Kelautan Dan Perikanan N0 49 Tahun 2011 tentang Perubahan Peraturan Menteri No 14 Tahun 2011.

\section{UNCLOS 1982}

Agreement Between the Government of the United States of America and the Government of the People's Republic of Cina Concerning Fisheries off the Coasts of the United States.

Agreement on Fisheries between The Government of Japan and The Government of Australia

Agreement On Fisheries between The Government of The Republic of Korea and The Government of Solomon Islands.

Fisheries Agreement Between the Government of New Zealand and the Government of Japan 
Bilateral Arrangement Between The Ministry of Marine Affairs And Fisheries of The Republic of Indonesia And The Ministry of Agriculture of The People's Republic of Cina On The Utilization of Part of The Total Allowable Catch in Indonesian Exclusive Economic Zone, 23 April 2000

Bilateral Arrangement between the Ministry of Marine Affairs and Fisheries of the Republic of Indonesia and the Ministry ofAgriculture and Cooperation of the Kingdom of Thailand on the Utilization of Part of theTotal Allowable Catch in Indonesian ExclusiveEconomic Zone 12 September 2002

Bilateral Arrangement Between The Ministery Of Marine Affairs And Fisheries Of The Republik Indonesia And The Department Og Agriculture Of The Republic Of The Philipines On The Utilization Of The Part Of The Total Allowable Catch In The Indonesian Exclusive Economic Zone. 